\title{
Derleme
}

\section{Ankilozan Spondilitte Laboratuar Bulguları}

\author{
Laboratory Findings of Ankylosing Spondylitis
}

\author{
Arzu ATICI ${ }^{1}$ \\ 1. Sağglı Bilimleri Üniversitesi, Fatih Sultan Mehmet Ĕ̈itim ve Araştırma Hastanesi, Fiziksel Tip ve Rehabilitasyon Kliniği, İstanbul
}

\section{$\ddot{O Z Z E T}$}

Ankilozan spondilit, sakroiliak eklemler ve omurga tutulumu ile karakterize spondilartropati grubundan sistemik inflamatuar bir hastalıktır. Hastalığın semptomları siklıkla geç adolesan veya erken erişkin dönemde başlar. Tanı klinik, laboratuar ve radyolojik bulgulara dayanır. AS için spesifik laboratuar testleri yoktur. Ancak hastalık aktivitesini değerlendirmek için akut faz reaktanlarl, sinıflama için ise HLA B-27 sıklıkla kullanılmaktadır. Bu makalede ankilozan spondilitte kullanılan laboratuar bulguları tartışılacaktır.

Anahtar Kelimeler: ankilozan spondilit, laboratuar testler, $C R P, H L A-B 27$

\section{ABSTRACT}

Ankylosing spondylitis is a systemic chronic inflammatory disease that mainly affects the sacroiliac joint and spine. It is a type of spondyloarthritis. Symptoms usually start at late adolescent or early adult period. Diagnosis is based on a combination of clinical, laboratory and radiology findings. There is no specific diagnostic laboratory test, but acute phase reactants indicate disease activity and classification criteria include HLA-B27 test. Laboratory findings of ankylosing spondylitis is discussed in this article.

Keywords: ankylosing spondylitis, laboratory tests, CRP, HLA-B27

\section{Iletişim Bilgileri}

Sorumlu Yazar: Arzu ATICI, Uzm. Dr.

Yazışma Adresi: Sağlık Bilimleri Ünv., Fatih Sultan Mehmet Eğitim ve Araștırma Hastanesi, E-5 Karayolu Üzeri, iç̧erenköy, Ataşehir, İstanbul Tel: +90 (216) 5783000

E-Posta: arzususinatici@gmail.com

Makalenin Geliş Tarihi: 21.03.2017

Makalenin Kabul Tarihi: 08.06.2017

\section{GíRiș}

Ankilozan spondilit (AS), kendine özgü klinik, fizyopatolojik, radyografik ve genetik özellikleri olan etyolojisi kesin olarak bilinmeyen, sakroiliak ve omurga eklem tutulumu ile karakterize kronik romatizmal bir hastalıktır (1). İnflamatuar bel ağrısı ile karakterizedir. Omurgada kisitlılik ve fiziksel fonksiyon kaybına yol açacağı için erken tanı ve tedavisi oldukça önemlidir. Tanı klinik, muayene ve radyolojik bulgularla konulmaktadır. Daha sonra Assessement of Spondyloarthritis International Society (ASAS) tarafindan tanımlanan ASAS aksiyal spondilartrit siniflama kriterleriyle laboratuar bulgusu olarak CRP ve HLA-B27 de değerlendirmeye katılmıştır (2). Ayrıca akut faz reaktanlarından sedimentasyon ve CRP hastalık aktivitesi izleminde sıklıkla kullanılmaktadir.

Kronik hastalık olması ve diğer organ tutulumlarına bağlı olarak hematolojik ve biyokimyasal bulgular saptanabilir. Ayrıca günümüzde çeşitli biyolojik belirteçler de araştırılmaktadır.

\section{Hemogram, Biyokimya ve Otoantikorlar:}

Bazı şiddetli vakalarda orta derecede normositer anemi ve trombositoz görülebilir (3). Periferik kandaki lökositlerin sayısı normaldir.

Kemik kaynaklı serum ALP düzeyi bazı hastalarda orta derecede yükselebilir $(1,4)$. Kreatin kinazda hafif artış olabilir, ancak hastalık aktivitesi ile ilișkili değildir (5). Renal tutulum olursa üre, kreatinin değerleri yükselebilir ve idrar tetkikinde proteinüri veya hematüri saptanabilir (6). RF negatiftir ya da normal toplumdakine benzer düşük titrede pozitif olabilir. Otoantikorlar genellikle negatiftir. Serum kompleman düzeyleri normal ya da artmış olabilir. Serum Ig A düzeyleri hastaların çoğunda artmaktadır ve akut faz reaktanlarıyla, hastalık aktivitesiyle ve periferik eklem tutulumuyla korelasyon göstermektedir (1). 


\section{Akut faz reaktanları:}

Akut faz yanit1, inflamasyon, doku hasar1, bakteriyel enfeksiyon, malignite, travma ve cerrahi işlemler sonrasında ortaya çıkan nonspesifik bir reaksiyondur. Hem akut hem de süregelen inflamasyonun yansimasidir. Akut faz proteinleri, aktive olmuş monosit, makrofaj, endotel hücreleri ve diğer hücreler tarafindan salınan IL-6, IL-1 ve TNF gibi sitokinler tarafindan uyarılır ve hepatositler tarafindan üretilirler (7). Pozitif reaktanlar yani inflamasyon sirasinda artan en önemli akut faz proteinleri: CRP, Fibrinojen, alfa1-antitripsin, haptoglobulin, seruloplazmin, serum amiloid protein A ve özellikle kompleman 3 başta olmak üzere değişik kompleman komponentleridir. Negatif akut faz reaktanlarından başlıcaları ise albumin, transferin, alfa-fetoprotein, transtretin saylabi$\operatorname{lir}(8,9)$.

Akut faz proteinleri patojenlerin fonksiyonlarını kolaylaştırır ve inflamatuar hücrelerden salınan proteolitik enzim ve serbest oksijen radikallerini inhibe ederek, doku hasarını önler ve hasar gören dokuların onarımına katkıda bulunurlar (10).

Sedimentasyon (ESH): Akut faz proteinlerindeki artışı indirek olarak gösteren bir yöntem olsa da günümüzde hala çok yaygın olarak kullanılan bir tetkiktir. $0.4 \mathrm{cc}$ sitrat ile $1.6 \mathrm{cc}$ kan karıștırılır ve bu karıșımdaki eritrositlerin $200 \mathrm{~mm}$ 'lik Westergreen tüpündeki 1 saatte çökme miktarı olarak ölçülür. Erkeklerde $15 \mathrm{~mm} / \mathrm{h}$, kadınlarda $20 \mathrm{~mm} / \mathrm{h}$ 'e kadar normal kabul edilir. ESH yaşla birlikte artar. Ayrıca cinsiyet, tokluk, gebelik gibi çeşitli faktörlerden etkilenir. Saklanmış örneklerde bakılamaz (10). Plazma fibrinojen düzeyinin yükselmesi eritrositlerin agregasyonu ile eritrosit sedimentasyon hızında (ESH) artışa yol açar (11). Alfa2 makroglobulin ve immünglobulinler gibi çeşitli proteinlerin arttığı mono ve poliklonal gamapati durumlarında ve eritrosit düzeyi azaldığında ESH yükselir. Orak hücreli anemi, polisitemi, sferositoz, hepatik ve kardiyak yetmezlikte ise ESH azalır (10).

C-reaktifprotein (CRP): CRP'yebu isim, Streptococcus pneumoniae'nın C-polisakkaridini presipite edebildiği için verilmiştir (12). Gelişimini yüzmilyonlarca yıl korumuş, 23-kD subünitlerine non-kovalent olarak bağlanan 5 benzer subunit içeren bir pentamerdir. Tüm insanların plazmasinda eser miktarda mevcuttur (12). CRP, infeksiyonun, travmanın, inflamatuar romatizmal ve malign hastalıkların yol açtı$\breve{g} 1$ inflamasyonu en iyi gösteren ve en yaygın kullanılan testtir. CRP'nin sentezi esas olarak karaciğerde, inflamasyon olan dokudan salg1lanan başta IL-6 olmak üzere sitokinlerin etkisi ile gerçekleşir (12). Serum CRP düzeyleri radioimmunassay, enzim immunoassay ve lazer nefelemetri ile $\mathrm{mg} / \mathrm{dl}, \mathrm{mg} / \mathrm{L}$ veya microgram/ ml olarak ölçülebilir (7). Sağlıklı genç bireylerde serum CRP düzeyi ortalama $1 \mathrm{mg} / \mathrm{L}$ 'dir (14).

ESH ve CRP AS hastalarının \%50-70'inde yüksek bulunmaktadır (15). Periferik eklem tutulumu veya inflamatuar barsak hastalığı ile birlikte olanlarda ESH ve CRP daha çok yükselmektedir (16). Yüksek serum CRP düzeylerinin sakroiliit progresyonunda güçlü pozitif bir gösterge olduğu da saptanmıştır (3).

Serum Amiloid A (SAA): Bir apolipoproteindir. Primer sentez yeri karaciğerdir, ancak ekstrahepatik üretim de bildirilmiștir. SAA sentezinin başlatılmasında öncelikle IL-1 ve IL-6 olmak üzere çeşitli sitokinler ve TNF rol oynamaktadır. Ekstrasellüler matriksi parçalayan enzimleri uyarır ve inflamatuar hücrelerin inflamasyon bölgesine kemotaksisini sağlar.

Amiloidozda depolanan Amiloid A proteininin prekürsörüdür. SAA düzeylerinde artan yaşla birlikte değişiklik saptanmamıştır. Enfeksiyöz veya nonenfeksiyöz inflamasyonda 6-8 saat içinde normal değerlerini 1000 katına çıkabilmektedir. CRP'ye göre daha erken ve daha hız11 yükselmektedir (8).

Yapılan bir çalışmada AS hastalarında SAA düzeylerindeki artışı ESR, CRP ve klinik aktivite skoru BASDAI ile önemli korelasyon gösterdiği saptanmıştır (17). Başka bir çalışmada ise inflamatuar markerlardan özellikle CRP ve SAA'nın etanercept ve infliximab tedavisi alan AS hastalarında inflamasyonun izleminde faydalı olduğu gösterilmiştir (18). ESH, CRP gibi inflamatuar hastalık markerları AS hastalarının çoğunda yükselse de tüm hastalarda artış olmamaktadir ve hastaların semptomlariyla ve radyolojik progresyonla her zaman korelelasyon göstermemektedir. Bundan dolayı bu markerlar AS hastalık aktivitesini izlemde her zaman yardımcı olamamaktadırlar (3). Bu da hastalık aktivitesi ve tedaviye cevabın değerlendirilmesi için daha kesin belirteçlerin gerekliliğini ortaya koymaktadır. Günümüzde bu amaçla çeşitli biyolojik belirteçler araştırılmaktadır.

\section{Biyolojik Belirteçler:}

Matrixmetalloproteinazlart (MMP) ve Metalloproteinazların doku ihibitörleri (TIMP): Kronik artritlerin patolojik özelliği ekstrasellülermatriks (ESM) komponentlerinin degradasyonudur. 
MMP'lerin ekstrasellülermatriksin degradasyon ve remodeling sürecinde önemli rolleri vardır ve normal fizyolojik sürecin yanı sıra birçok artrit, kanser ve kardiyovasküler hastalık gibi patolojik süreçlerde de rol oynarlar. MMP'ler artriti olanlarda fibroblastlar, makrofajlar, sinovyal hücreler, endotelyal hücreler, nötrofiller ve kondrositler tarafindan IL-1, TNF alfa gibi proinflamatuar sitokinlerin uyarılmasina yanit olarak salgilanır. MMP aktivitesi alfa-2 makrogobulinler ile TIMP gibi inhibitörler tarafindan regüle edilir. MMP ve inhibitörleri arasındaki dengenin bozulması inflame eklemde EkstraSellüler Matriks (ESM) degradasyonu ile sonuçlanır $(19,20)$.

MMP ve TIMP serum düzeylerinin hastalık aktivitesini saptamada klinik yararı araştırılan, 42 AS hastası ve 20 sağlıklı bireyde yapılan bir çalışmada, MMP'ler arasında sadece MMP3'ün düzeyi sağlıklı kontrol grubuna göre yüksek bulunmuştur. Ayrıca MMP3 düzeyi ile BASDAI arasında da pozitif korelasyon saptanmış ve korelasyon 1 yıllık izlemde devam etmiştir. MMP3'ün AS'de yüksek hastalık aktivitesinin belirlenmesinde sedimentasyon ve CRP'ye göre daha hassas olduğu saptanmıştır (21).

\section{Sitokinler:}

Makrofaj koloni stimüle edicifaktör (M-CSF): AS hastalarında M-CSF'nin rolü araştırılmıştır. Yapılan bir çalışmada 41 AS hastasında serum M-CSF düzeyi sağlıklı kontrollere göre anlamlı olarak yüksek bulunmuş. Ayrıca serum M-CSF düzeyleri ile BASDAI, sedimentasyon ve serum IgA düzeyleri arasında anlamlı korelasyon saptanmıştır (19).

IL-6: Serum IL-6 seviyelerinin AS'li hastalarda sağlıklı bireylere göre daha yüksek olduğu bilinmektedir (22). Aktif hastalığ IL-6 düzeyinin daha da yüksek olduğu saptanmıştır (23). Çeşitli araştırmalarda IL-6 ile $\mathrm{ESH}$, trombosit say1s1, tutukluk (vizuel analog skor), BASDAI, fiziksel mobilite düzeyi gibi parametreler arasinda korelasyon bulunmuştur (20). Multipl regresyon analizleri göstermiştir ki IL-6 düzeyindeki erken azalma, BASDAI skorundaki ve spinal magnetik rezonans görüntüleme (MRG) aktivite düzeyindeki iyileşme ile önemli derecede ilişki bulunmaktadır (24).

Kartilaj ve Kemik Biyolojik Belirteçleri: Artiküler katrilaj başlica proteoglikan agrekanla kompleks yapmış Tip II kollajen fibrillerden oluşur. Dejeneratif ve inflamatuar eklem hastalığında Tip II kollajenin ayrılmasıyla neopitoplar oluşur. $\mathrm{C} 2 \mathrm{C}$ ve $\mathrm{C} 1,2 \mathrm{C}$ neoepitopları degradasyon belirteci olarak kabul edilmektedir.
Tip II kollejen sentezi, kartilajda TipII kollajen C-propeptid (CPII) ile direk orantilıdır. $\mathrm{CPII} / 2 \mathrm{C}$ oran tip II kollajen sentez ve degradasyon dengesini yansitır. Esas kartilajproteoglikanı olan agrekandır. Agrekan döngüsündeki artış1 aggrekanepitopu (846) yansıtır $(20,25)$. Yapılan bir çalışmada AS'li hastalarda serum CPII, CPII/C2C oranı, agekan 846 epitopu sağlıklı kontrol grubuna göre anlamlı olarak yüksek bulunmuştur ve CPII/C2C oranının CRP düzeyleri ile korele olduğu gösterilmiştir. Serum CPII ve 846 epitopunun hyalin kıkırdak ve intervertebral disklerdeki biyosentez döngüsü ile ilişkili olabileceği ve enkondral ossifikasyonun sonucu olan progresif kemik formasyonunu yansıtabileceği bildirilmiştir (26).

\section{Genetik Testler:}

Patogenezinde genetik etmenlerin en fazla rol oynadığı romatizmal hastalık olan AS ile ilgili olarak çok sayıda HLA ve HLA dışı gen araştırılmıştır. Artık AS ile en güçlü ilişskinin HLA-B27 genleri arasında olduğu bilinmektedir.

HLA B27, MHC sinıf I moleküllerinin HLA-B allelidir ve AS için genetik sorumluluk taşıyan belirteçlerin en iyi tanınanıdır (27). AS hastalarında \% 74-89 oranında HLA-B27 pozitiftir. HLA B-27 pozitif bireylerde AS için risk \%2-10 arasındadır (28). Bu da göstermektedir ki HLA B-27 AS için oldukça sensitiftir, ancak spesifitesi düşüktür. AS HLA B-27 yokluğunda da oluşabileceği için rutin taramada kullanılması uygun değildir (1). Ancak ASAS sinıflama kriterlerine göre kliniğin olduğu ancak radyolojik olarak sakroileit saptanmadığı durumlarda önem taşımaktadır (28).

HLA B27'nin 140'tan daha fazla alt tipi tespit edilmiştir (27). Hepsi AS ile ilişkili değildir. AS ile ilişkisi olan alt tiplerin en sik rastlanılanı HLA-B*27:05, B27:01, B*27:02, B*27:04 ve $B * 27: 07$ 'dir (27). Baz1 bulgular HLA-B27 pozitif hastalarda, negatif olanlara göre hastalığın daha şiddetli olabileceğini göstermekle birlikte bu konuda yeterli çalışma bulunmamaktadır (29).

Genetik çalışmalar sonucu AS'in, HLA B-27'den başka HLA-B40, HLA-B51, HLA-B7, HLA-A2 ve HLA-DRB1'in de AS için predispozan faktör olduğu gösterilmiştir (30).

Sinovyal Sivı Analizi: Ankilozan spondilitte periferik eklem tutulumu varlığında eklemden yapılan sinovyal sıvı analizi, diğer inflamatuar artritlerden farkl1l1k göstermemektedir. 
Normal sinovyal sıvı berrak, renksiz veya açı sarı ve akışkandır. Efüzyonun bulanık olması inflamatuar hücrelerin varlığını gösterir. İnflamatuar artritlerde sinovyal sıvının akışkanlığı azalır. 2000-50000 hücre/ $\mathrm{mm}^{3}$ inflamatuar olarak tanımlanır (31).

Solunum Fonksiyon Testleri: AS'de göğüs ekspansiyonunda azalma akciğer kapasitesinde dispneye yol açacak kadar azalmaya sebep olmaz. Diyafragmatik katılımda artma yeterli ventilasyonu sağlayabilir. Ancak nadiren de olsa AS hastalarında parankim ve plevral tutulum olabilir ve parankimal tutulumla ilişkili olarak restriktif akciğer hastalığı görülebilir (5). Böyle hastalarda SFT'de vital kapasitede azalma ve fonksiyonel rezidüel volümde artış saptanır (15).

\section{KAYNAKLAR}

1. Kamanl A, Gülkesen A. Ankilozan spondilit ve romatoid artritin sistemik karşılaştırması. Türkiye Klinikleri J Immunol Rheumatol-Special Topics 2011;4 (1):89-98.

2. Rudwaleit M, Van der Heijde D, Landewe R, Listing J, Akkoc $N$, Brandt $J$, et al. The development of assessment of spondyloarthritis international society classification criteria for axial spondyloarthritis (part II): validation and final selection. Ann Rheum Dis 2009; 68 (6):777-83.

3. Ehrenfeld M. Spondyloarthropathies. Best Practice\&Research Clin Rheum 2012;26: 135-145.

4. Kabasakal Y. Spondilartritler. Gümüsdis G, Doğanavsargil E. Klinik Romatoloji. İstanbul: Deniz matbaast; 1999. sy:147-159.

5. Özgöçmen S. Ankilozan spondilitin klinik ve laboratuar bulguları. Romatoloji. Ed. Ataman Ş, Yalçın P. Ankara: NM \& Medikal Nobel Tip Kitabevi; 2012. sy:583-596.

6. Celiker R. Ankilozan spondilit klinik özellikleri. Romatizma 2000;15: 15-21.

7. Doğan ŞK, Tur BS. Akut faz proteinleri. Romatoloji. Ed. Ataman Ş, Yalçın P. Ankara: NM \& Medikal Nobel Tip Kitabevi 2012. sy: 201-208.

8. Batırel A, Gençer S, Özer S. Enfeksiyon göstergesi olarak akut faz reaktanlarl: CRP ve Serum amiloid A (SAA). Kartal Eğitim ve Araştırma Hastanesi Tip Dergisi 2003; 14(3):220-224.

9. Singh NK, Varshney AN, Meena RP. Serum amyloid $A$ as a sensitive marker of disaese activity in rheumatic diseases. Internet Journal of Rheumatology and Clinical Immunology 2014; 2(S1):1-6

10. Keser G. Romatolojik hastalıkların tanısinda hematolojik, biyokimyasal ve seroimmünolojik incelemeler. Gümüsdiş $G$, Doğanavşargil, editörler. E. Klinik Romatoloji. İstanbul: Deniz Matbaasi, 1999. sy: 147-159.

11. Wilk AS, Fritzler MJ. Romatizmal hastaliklarda laboratuar testler. Çev. Ed. Arasil T . Ankara: Rotatıp Kitabevi 2011. sy: 219-237.

12. Yücel AE. C-Reaktif Protein ve diğer akut faz proteinlerinin klinik kullanımı. Türkiye Tıp Dergisi 2004; 11(1): 42-52.

13. Ballou SP, Kushner I. Inflamasyonun laboratuar değerlendirmesi. Çev. Ed. Arasıl T. Kelley Romatoloji, Ankara: Güneş Kitabevi 2006. sy: 720-727.
14. Hutchinson WL, Koenig W, Fröhlich M, Sund M, Lowe G, Pepys MB. Immunoradiometric assay of circulating $C$-reactive protein: age-related values in the adult general population. Clin Chem 2000 ;46(7): 934-38.

15. J Sieper, J Braun, M Rudwaleit, A Boonen, A Zink. Ankylosing spondylitis: an overview. Extended report. Ann Rheum Dis 2002;61(Suppl III):iii8-iii18

16. Zochling J, Braun J. Assesment of ankylosing spondylitis. Clin Exp Rheumatol 2005; 23(Supp 39):133-41.

17. Lange U, Boss B, Teichmann J, Klor HU, Neeck G. Serum amyloid A: an indicator of inflammation in ankylosing spondylitis. Rheumatol Int. 2000;19:119-22.

18. de Vries MK, van Eijk IC, van der Horst-Bruinsma IE, Peters MJ, Nurmohamed MT, Dijkmans BA, Hazenberg BP, Wolbink GJ. Erythrocyte sedimentation rate, $C$-reactive protein level, and serum amyloid A protein for Patient selection and monitoring of anti-tumor necrosis factor treatment in ankylosing spondylitis. Arthritis Rheum 2009; 61(11): 1484-90.

19. Chen CH, Yan Yu DT, Chou CT. Biomarkers in spondyloarthropathies. In: Lopez-LarreaC,Diaz-Pena R, eds. Molecular mechanism of spondyloarthropathies. Landes Bioscience and Springer Science + Business Media, 2009. p.122-32.

20. Bodur H. Ankilozan spondilitte biyolojik belirteçler. Türkiye Klinikleri J Immunol Rheumatol-Special Topics 2011;4(1):237.

21. Chen $C H$, Lin KC, Yu DTY, Yang C, Huang $F$, Chen HA et al. Serum matrixmetallo proteinases and tissue inhibitors of metalloproteinases in ankylosing spondylitis: $M M P-3$ is a reproducibly sensitive and specific biomarker of disease activity. Rheumatology 2006;45 (4):414-420

22. Bal A, Ünlü E, Bahar G, Aydoğ E, Ekșioğlu E, Yorgancioğlu R. Comparison of serum $I L-1 \beta$, sIL-2R, IL-6, and TNF- $\alpha$ levels with disease activity parameters in ankylosing spondylitis. Clin Rheumatol, 2007;26:211-215.

23. Gratacos J, Collado A, Pons F, Osaba M, Sanmartı R, Roque M, Larrosa M, J. Munoz-gomez. Significantloss of bone mass in patients with early, active ankylosing spondylitis. Arthritis Rheum 1999; 42 (11): 2319-2324.

24. Visvanathan S, Wagner C, Marini JC, Baker D, Gathany T, Han J, et al. Inflammatory biomarkers, disease activity and spinal disease measures in patients with ankylosing spondylitis after treatment with infliximab. Ann Rheum Dis 2008; 67:5117.

25. Vlam K. Soluble and tissue biomarkers in ankylosing spondylitis. Best Practice\&Research Clinical Rheumatology 2010 (24); 671-682.

26. Kim TH, Stone M, Payne U, Zhang X, Ionescu M, Lobanok T, King L, Poole AR, Inman RD. Cartilage biomarkers in ankylosing spondylitis relationship to clinical variables and treatment response. Arthritis Rheum. 2005; 885-891.

27. Kaya T. Ankilozan spondilitte etiyoloji ve patogenez, Ataman S,, Yalçın P, editörler. Romatoloji. Ankara: NM\& Medikal Nobel Tip Kitabevi. Sy: 575-582.

28. Taurog JD, Chhabra A, Colbert R. Ankylosing spondylitis and axial spondyloarthritis. $N$ Engl J Med 2016; 374:25632574.

29. Maksymowych WP. Ankilozan spondilitin etiyolojisi, patogenezi ve patolojisi. Cev.Ed.Arasil T. Ankara: Rotatıp Kitabevi 2011. sy: 1115-1129.

30. Sieper J, Poddubnyy D. Axial spondyloarthritis. Lancet 2017. doi.org/10.1016/S0140-6736(16)31591-4.

31. Wise C. Eklem ve yumuşak dokuların artrosentez ve enjeksiyonlart. Çev.Ed.Arasıl T. KelleyRomatoloji. sy:692-709. 